\title{
Meta-Analysis of the Effectiveness of Using Antiplatelet Drugs Uptake in Decreasing Mortality in COVID-19 Patients
}

\author{
Happy Nurhayati1), Eti Poncorini Pamungkasari²), Bhisma Murti1) \\ ${ }^{1)}$ Masters Program in Public Health, Universitas Sebelas Maret \\ ${ }^{2)}$ Faculty of Medicine, Universitas Sebelas Maret
}

\section{ABSTRACT}

Background: Viscoelastic coagulation testing in COVID-19 patients often found elevated concentrations of D-dimer and fibrinogen. Thrombotic complications can be in the form of Venous Thromboembolism (VTE), where this thrombotic disease is one of the factors associated with increased mortality of COVID-19 patients. This study aims to analyze the effectiveness of antiplatelet drugs in reducing mortality in COVID-19 patients.

Subjects and Method: This is a meta-analysis study using PRISMA flowchart guidelines. The article search process was carried out between 2020-2021 using PubMed, Science direct, Google Scholar, and Scopus databases. The article search was carried out by considering the eligibility criteria defined in the PICO model. Population= COVID-19 patients, Intervention= using antiplatelet drugs, Comparison= not using anticoagulant drugs, Outcome = mortality. The keywords used were "antiplatelet" AND "mortality" AND "COVID-19". The inclusion criteria used were English full-text cohort papers and the relationship measure used as the adjusted odds ratio (aOR). Based on the database, 9 articles fulfilled the inclusion criteria. The analysis was carried out using RevMan 5.3 software.

Results: The meta-analysis was carried out on 9 articles from the UK, Spain, Germany, Poland, America, Israel, and China. The results of data processing showed that COVID-19 patients who received antiplatelet drugs had a 0.70 times risk of dying than those without antiplatelet drugs, and it was not statistically significant $(\mathrm{aOR}=0.70 ; \mathrm{CI} 95 \%=0.46$ to $1.07 ; \mathrm{p}=0.100)$.

Conclusion: The use of anticoagulant drugs reduces the mortality risk of COVID-19 patients, but it is not statistically significant.

Keywords: antiplatelet, mortality, COVID-19

\section{Correspondence:}

Happy Nurhayati. Masters Program in Public Health, Universitas Sebelas Maret. Jl. Ir. Sutami 36A, Surakarta 57126, Central Java. Email: happyajja3@gmail.com. Phone: +62 812-2616-0538.

\section{Cite this as:}

Nurhayati H, Pamungkasari EP, Murti B (2021). Meta-Analysis of the Effectiveness of Using Antiplatelet Drugs Uptake in Decreasing Mortality in COVID-19 Patients. Indones $J$ Med. 06(03): 315-324. https://doi.org/10.26911/theijmed.2021.06.03.09.

cc) (7)(2) Indonesian Journal of Medicine is licensed under a Creative Commons

EY NC SA Attribution-Non Commercial-Share Alike 4.0 International License.

\section{BACKGROUND}

In December 2019, the coronavirus disease (COVID-19), caused by infection with a new coronavirus, officially named Severe Acute Respiratory Syndrome Corona Virus-2 (SARS-CoV-2), was first reported in Wuhan, Hubei Province, China (Yuan et al., 2021). On March 11, 2020, the World Health Organization (WHO) declared the coronavirus disease
(COVID-19) outbreak a pandemic. In December 2020 , WHO reported the number of confirmed cases globally was $4,288,180$, with the number of deaths from COVID-19 by 83,291 cases. Meanwhile, Indonesia reported 51,985 confirmed cases with 1,497 deaths. The worldwide COVID-19 data updated on December 8, 2021, published by the WHO Coronavirus (COVID-19) dashboard, the total 
global COVID-19 cases currently are 266,504,411 cases $5,268,849$ of them passed away. The United States became the country with the highest number of cases, 98,027,251, and the highest number of deaths from COVID-19, with 2,363,738 cases. In Indonesia, the death rate due to COVID-19 was observed to be quite high, which are 143,893 cases, and the total confirmed has reached 4,258,076 cases.

The most common clinical features of COVID-19 include fever, respiratory symptoms, and myalgia. However, lung problems and systemic inflammation develop in severe cases, resulting in diffuse alveolar damage, multiple organ dysfunction, and death. In addition, the key pathological features of COVID-19 include virus-mediated damage, especially in the respiratory tract and multiple organs, activation of immune responses following the release of inflammatory procytokines, overactivation of the coagulation cascade, and platelet aggregation that can lead to thrombosis (Son et al., 2021).

Antiplatelet is a type of blood-thinning medication. Acetylsalicylic acid or aspirin is an antiplatelet drug that is easily found on the market and functions to inhibit platelet aggregation. The main biochemical mechanism by which antiplatelet agents (aspirin) inhibit thrombotic damage is through irreversible inactivation of the enzyme cyclooxygenase 1 (COX-1) (Diaz et al., 2020). In a study conducted by Aghajani et al. (2021) in patients with a confirmed diagnosis of severe COVID-19 admitted to the Imam Hossein Medical Center, Tehran, Iran from March 2019 to July 2020 it was found that out of 991 hospitalized patients, 336 patients (34\%) were given aspirin during their hospitalization and 655 people (66\%) were not given aspirin, suggesting a significant independent relationship between aspirin use and a reduced risk of in-hospital death $(\mathrm{OR}=0.75 ; \mathrm{CI}$ $95 \%=0.56$ to $0.99 ; p=0.046)$.
Meta-analysis is an epidemiological study used to combine and statistically combine the results of a number of in-dependent primary studies so that a large number of research samples are found and can obtain the highest pyramid in the research strata.

Problems related to the increase in cardiovascular complications, especially in controlling blood viscosity, can be treated with anticoagulants and antiplatelet agents, as discussed in many scientific studies worldwide. In service practice at the hospital where the researcher works, the therapy that is often used to treat high $\mathrm{D}$ dimers is using anticoagulants only. However, it is easier to find antiplatelets in the market (pharmacies), while the availability of anticoagulant drugs tends to be more difficult to obtain. This underlies the researcher to choose the theme of the study carried out. This study aims to analyze the effectiveness of antiplatelet drugs in reducing mortality in COVID-19 patients.

\section{SUBJECTS AND METHOD}

\section{Study Design}

This study used a systematic review method and meta-analysis with secondary data through the database, this study produced a summary by using the PRISMA flow diagram. Article searches were conducted through the internet using databases from PubMed, Science Direct, Google Scholar, and Scopus. The keywords used were "antiplatelet" AND "mortality" AND "COVID-19".

\section{Inclusion Criteria}

The inclusion criteria in selecting the articles were full-text cohort papers, in English and the relationship measure used as the adjusted odds ratio (aOR).

\section{Exclusion Criteria}

The exclusion criteria used were to exclude articles published that were not in English and articles published before 2020. 


\section{Definition of Operational Variable}

The search for articles was carried out by considering the eligibility criteria determined by using the PICO model. The study population was patients with confirmed COVID-19 who used antiplatelet drugs compared to those who did not use antiplatelet drugs, and the outcome mortality.

Antiplatelet drugs are drugs used to prevent the formation of blood clots by inhibiting the activation of platelets during the blood clotting process.

Mortality is the number of deaths due to certain diseases or natural deaths. The focus of this study is the number of deaths of patients with COVID-19.

\section{Instrument of the Study}

The stages of this study followed the PRISMA flow diagram and the study quality assess- ment was carried out quantitatively and qualitatively using a critical appraisal check-list for cohort studies (CEBMa, 2014).

\section{Data Analysis}

Data in the form of selected published research articles and Meta-Analysis were carried out, processed using analysis software, namely Review Manager 5.3 (RevMan 5.3) issued by the Cochrane Colla-boration. The article results described the confidence interval (CI) and adjusted odds ratio (aOR).

\section{RESULTS}

The article search process was carried out through the database according to the PRISMA flow diagram and can be seen in Figure 1 below.

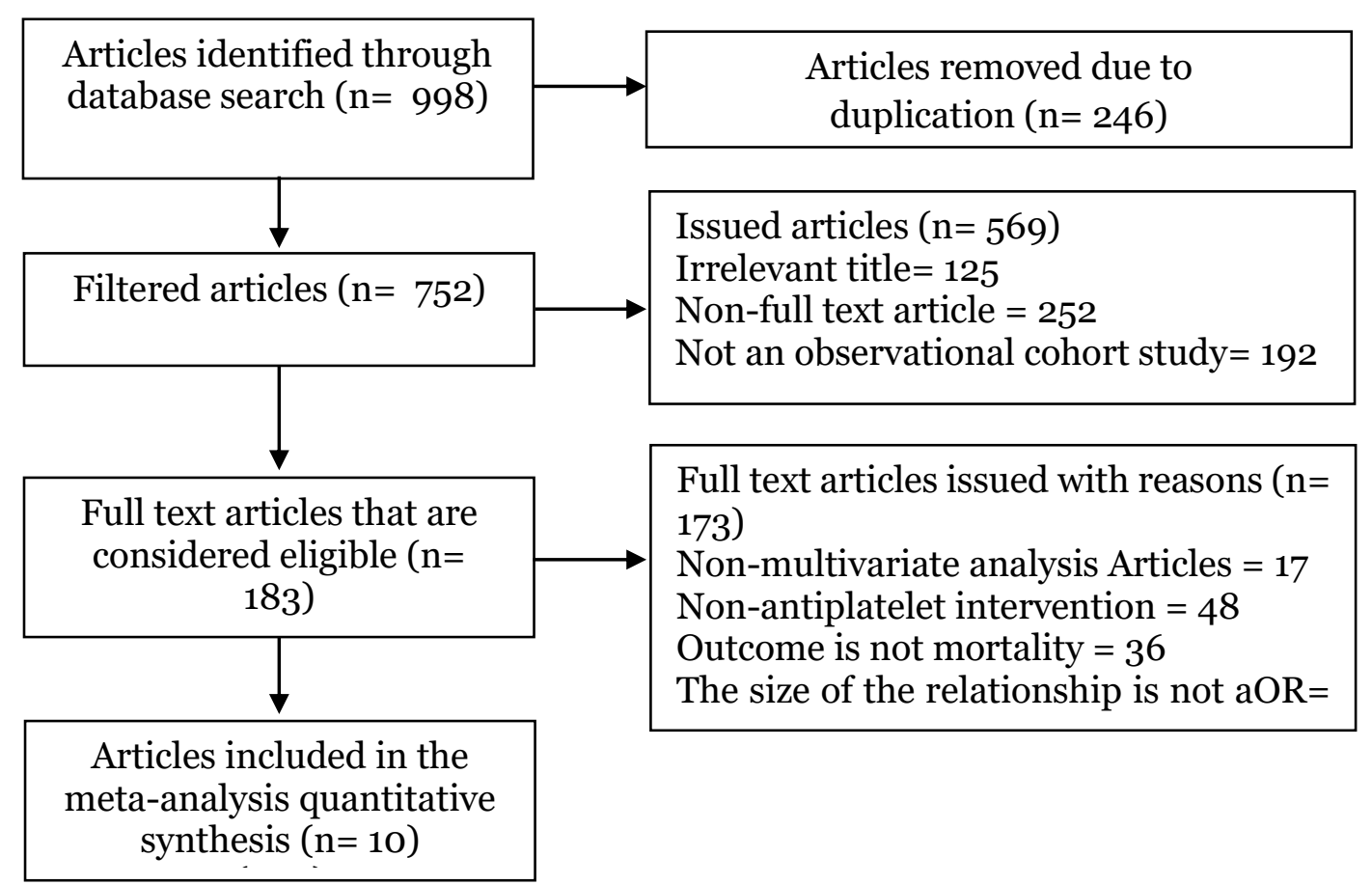

Figure 1. PRISMA flow Diagram 
Table 1. Critical Appraisal Checklist cohort study of the effectiveness of using antiplatelet drugs in reducing mortality in COVID-19 patients

\begin{tabular}{|c|c|c|c|c|c|c|c|c|c|c|}
\hline \multirow[b]{2}{*}{ Checklist Questions } & \multicolumn{10}{|c|}{ Publications (Author and Year) } \\
\hline & $\begin{array}{l}\text { Abu- } \\
\text { Jamous et } \\
\text { al. (2020) }\end{array}$ & $\begin{array}{c}\text { Benson } \\
\text { et al. } \\
\text { (2021) }\end{array}$ & $\begin{array}{l}\text { Corrochano } \\
\text { et al. (2021) }\end{array}$ & $\begin{array}{l}\text { Fröhlich et } \\
\text { al. (2021) }\end{array}$ & $\begin{array}{l}\text { Merzon et } \\
\text { al. (2021) }\end{array}$ & $\begin{array}{l}\text { Osborne } \\
\text { et al. } \\
\text { (2021) }\end{array}$ & $\begin{array}{l}\text { Sahai } \\
\text { et al. } \\
\text { (2021) }\end{array}$ & $\begin{array}{l}\text { Terlecki } \\
\text { et al. } \\
\text { (2021) }\end{array}$ & $\begin{array}{l}\text { Tremblay } \\
\text { et al. } \\
\text { (2020) }\end{array}$ & $\begin{array}{l}\text { Yuan et } \\
\text { al. } \\
(2020)\end{array}$ \\
\hline 1. Does the study address a focused problem? & 1 & 1 & 1 & 1 & 1 & 1 & 1 & 1 & 1 & 1 \\
\hline $\begin{array}{l}\text { 2. Is the cohort study method appropriate to answer the } \\
\text { study question? }\end{array}$ & 1 & 1 & 1 & 1 & 1 & 1 & 1 & 1 & 1 & 1 \\
\hline $\begin{array}{l}\text { 3. Are there enough subjects to establish that the } \\
\text { findings do not occur by chance? }\end{array}$ & 1 & 1 & 1 & 1 & 1 & 1 & 1 & 1 & 1 & 1 \\
\hline $\begin{array}{l}\text { 4. Is the cohort selection based on objective and } \\
\text { validated criteria? } \\
\text { Is the sample of subjects representative of the }\end{array}$ & 1 & 1 & 1 & 1 & 1 & 1 & 1 & 1 & 1 & 1 \\
\hline $\begin{array}{l}\text { 5. Is the sample of subjects representative of the } \\
\text { specified population? }\end{array}$ & 1 & 1 & 1 & 1 & 1 & 1 & 1 & 1 & 1 & 1 \\
\hline 6. Is the sample size based on pre-study considerations? & 1 & 1 & 1 & 1 & 1 & 1 & 1 & 1 & 1 & 1 \\
\hline 7. Are objective and unbiased outcome criteria used? & 1 & 1 & 1 & 1 & 1 & 1 & 1 & 1 & 1 & 1 \\
\hline 8. Are the measurements valid and reliable? & 1 & 1 & 1 & 1 & 1 & 1 & 1 & 1 & 1 & 1 \\
\hline 9. Is statistical significance assessed? & 1 & 1 & 1 & 1 & 1 & 1 & 1 & 1 & 1 & 1 \\
\hline 10. Is there a given confidence interval? & 1 & 1 & 1 & 1 & 1 & 1 & 1 & 1 & 1 & 1 \\
\hline $\begin{array}{l}\text { 11. Have the confounding factors been taken into } \\
\text { account? }\end{array}$ & o & 1 & 1 & 1 & 1 & 1 & 1 & 1 & 1 & o \\
\hline 12. Can the results be applied in this study? & 1 & 1 & 1 & 1 & 1 & 1 & 1 & 1 & 1 & 1 \\
\hline Total & 12 & $\mathbf{1 1}$ & 12 & 12 & 12 & 12 & 12 & 12 & 12 & $\mathbf{1 1}$ \\
\hline
\end{tabular}

Description: $\mathrm{Yes}=1 ; \mathrm{No}=2$ 
Nurhayati et al./ Antiplatelet Drugs Uptake in Decreasing Mortality in COVID-19 Patients

Table 2. Description of the primary cohort studies included in the meta-analysis

\begin{tabular}{|c|c|c|c|c|c|c|c|c|}
\hline Author (year) & Country & Study Design & Sample & $\begin{array}{c}\mathbf{P} \\
\text { (Population) }\end{array}$ & $\begin{array}{c}\text { I } \\
\text { (Intervention) }\end{array}$ & $\begin{array}{c}\mathrm{C} \\
\text { (Comparison) }\end{array}$ & $\begin{array}{c}\mathbf{O} \\
\text { (Outcome) }\end{array}$ & $\begin{array}{c}\text { aOR } \\
(\text { CI } 95 \%)\end{array}$ \\
\hline Abu-Jamous et al. (2020) & England & $\begin{array}{l}\text { Retrospective } \\
\text { Cohort }\end{array}$ & 1,253 & COVID-19 patients & Using antiplatelet & Without antiplatelet & Mortality & $\begin{array}{l}\mathrm{aOR}=0.10 \\
(0.02-0.59)\end{array}$ \\
\hline Benson et al. (2021) & England & Prospective Cohort & 1,103 & $\begin{array}{l}\text { COVID-19 patients with } \\
\text { vascular disease }\end{array}$ & Using antiplatelet & Without antiplatelet & Mortality & $\begin{array}{l}\mathrm{aOR}=0.51 \\
(0.18-0.94)\end{array}$ \\
\hline Corrochano et al. (2021) & Spain & $\begin{array}{l}\text { Retrospective } \\
\text { Cohort }\end{array}$ & 1,612 & COVID-19 patients & Using antiplatelet & Without antiplatelet & Mortality & $\begin{array}{l}\mathrm{aOR}=1.18 \\
(0.84-1.66)\end{array}$ \\
\hline Fröhlich et al. (2021) & Germany & $\begin{array}{l}\text { Retrospective } \\
\text { Cohort }\end{array}$ & 6,637 & $\begin{array}{l}\text { COVID-19 patients over the } \\
\text { age of } 18\end{array}$ & Using antiplatelet & Without antiplatelet & Mortality & $\begin{array}{l}\mathrm{aOR}=1.10 \\
(0.88-1.23)\end{array}$ \\
\hline Merzon et al. (2021) & Israel & $\begin{array}{l}\text { Retrospective } \\
\text { Cohort }\end{array}$ & 112 & $\begin{array}{l}\text { COVID-19 patients over the } \\
\text { age of } 40\end{array}$ & Using antiplatelet & Without antiplatelet & Mortality & $\begin{array}{l}\mathrm{aOR}=0.38 \\
(0.04-3.59)\end{array}$ \\
\hline Osborne et al. (2021) & America & $\begin{array}{l}\text { Retrospective } \\
\text { Cohort }\end{array}$ & 35,370 & $\begin{array}{l}\text { Veterans all over the } \\
\text { country with positive } \\
\text { COVID-19 }\end{array}$ & Using antiplatelet & Without antiplatelet & Mortality & $\begin{array}{l}\mathrm{aOR}=0.38 \\
(0.32-0.46)\end{array}$ \\
\hline Sahai et al. (2021) & America & $\begin{array}{l}\text { Retrospective } \\
\text { Cohort }\end{array}$ & 1,994 & COVID-19 patients & Using antiplatelet & Without antiplatelet & Mortality & $\begin{array}{l}\mathrm{aOR}=0.85 \\
(0.51-1.41)\end{array}$ \\
\hline Terlecki et al. (2021) & Poland & $\begin{array}{l}\text { Retrospective } \\
\text { Cohort }\end{array}$ & 1,729 & COVID-19 patients & Using antiplatelet & Without antiplatelet & Mortality & $\begin{array}{l}\mathrm{aOR}=0.65 \\
(0.42-0.98)\end{array}$ \\
\hline Tremblay et al. (2020) & America & $\begin{array}{l}\text { Retrospective } \\
\text { Cohort }\end{array}$ & 3,772 & COVID-19 patients & Using antiplatelet & Without antiplatelet & Mortality & $\begin{array}{l}\mathrm{aOR}=1.03 \\
(0.72-1.47)\end{array}$ \\
\hline Yuan et al. (2020) & China & $\begin{array}{l}\text { Retrospective } \\
\text { Cohort }\end{array}$ & 183 & $\begin{array}{l}\text { COVID-19 patients with } \\
\text { CAD }\end{array}$ & Using antiplatelet & Without antiplatelet & Mortality & $\begin{array}{l}\mathrm{aOR}=0.94 \\
(0.41-2.17)\end{array}$ \\
\hline
\end{tabular}


Nurhayati et al./ Antiplatelet Drugs Uptake in Decreasing Mortality in COVID-19 Patients

Articles on the effectiveness of using antiplatelet drugs in reducing mortality/ death of COVID-19 patients that fulfilled the qualitative require-ments and were reviewed again. There were 10 articles from 3 continents, namely: 5 articles from the European continent (from England, Spain, Germany, and Poland), 3 articles from the Americas (from all American countries), and 2 articles from the Asian continent (from Israel and China). Study quality research was carried out quantitatively and qualitatively using a critical appraisal checklist for cohort studies (CEBMa, 2014).

\section{Forest plot}

The interpretation of the results of the metaanalysis process can be seen from the forest plot. Figure 2 below showed that COVID-19 patients who received antiplatelet drugs had a 0.70 times risk of dying than those without antiplatelet drugs $(\mathrm{aOR}=0.70 ; 95 \% \mathrm{CI}=0.46$ to $1.07 ; \mathrm{p}=0.100$ ); however, it could be stated that it was not statistically significant. The heterogeneity of the research data showed the score of $\mathrm{I}^{2}=89 \%$ so that the data distribution was presented using a random effect model.

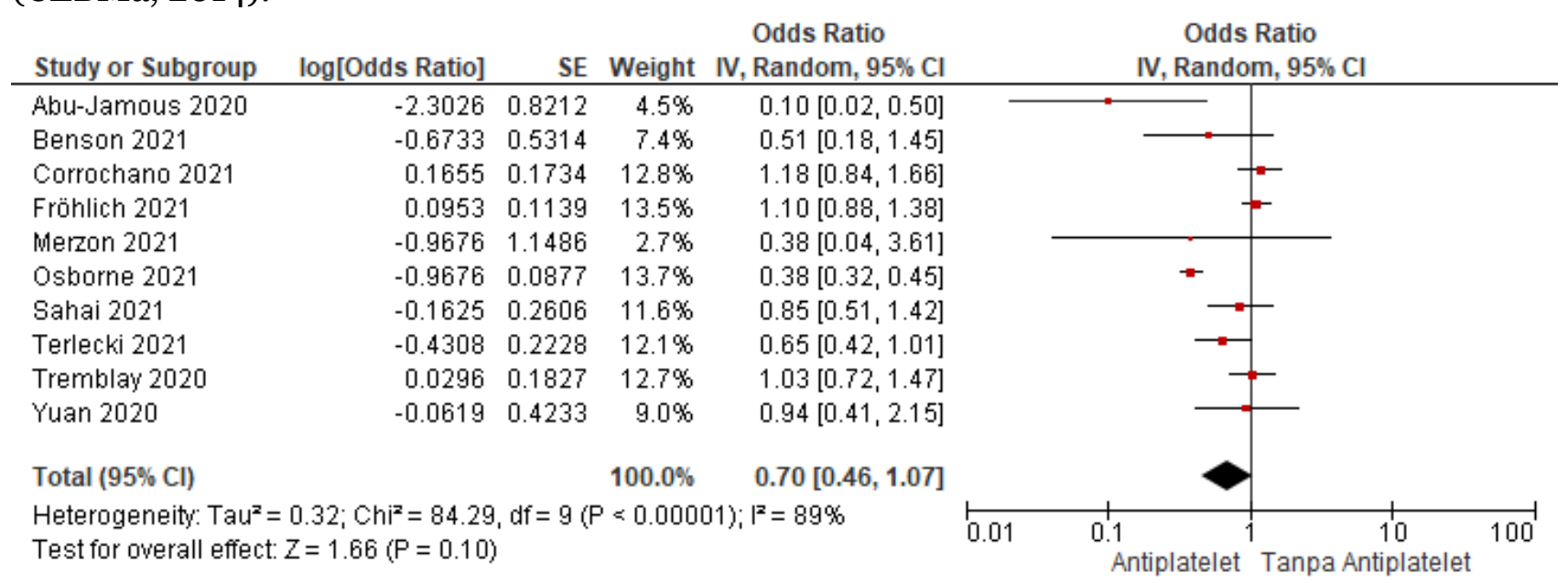

Figure 2. Forest Plot of the effectiveness of using antiplatelet

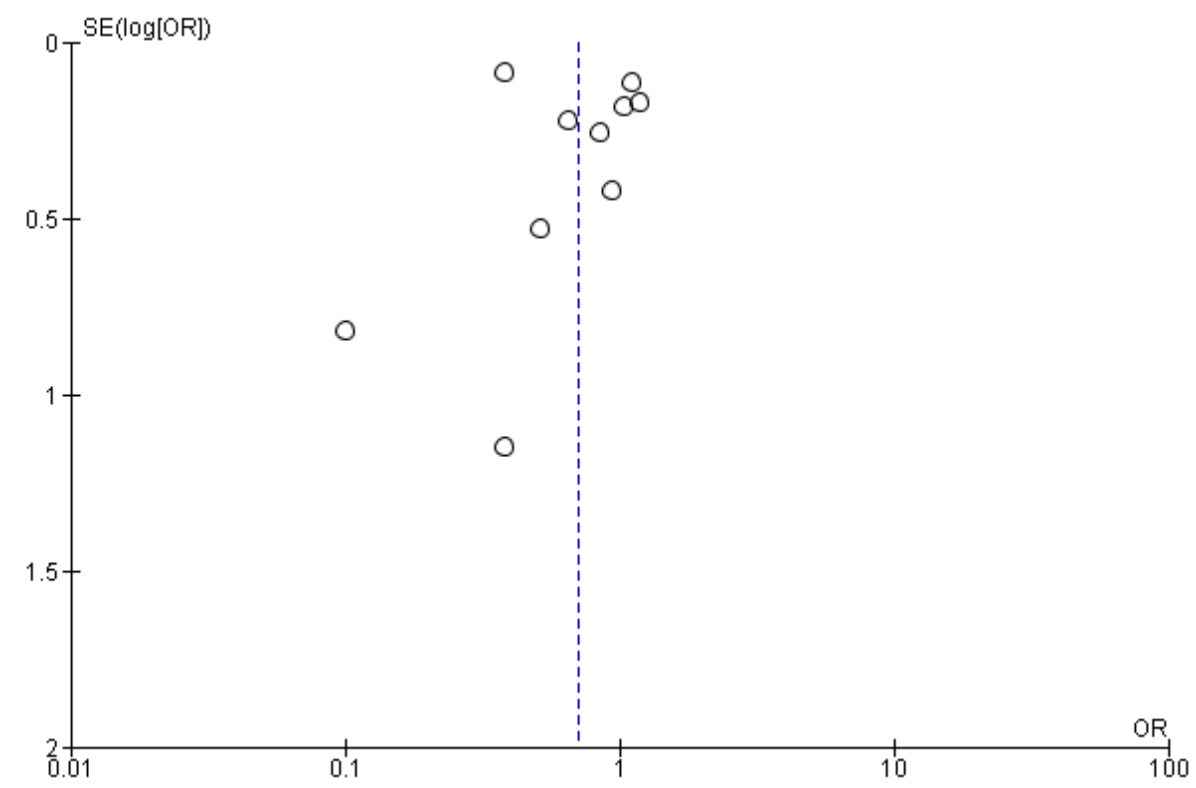

Figure 3. Funnel Plot of the effectiveness of using antiplatelet drugs in reducing the mortality rate of COVID-19 patients 


\section{Funnel plot}

In Figure 3, it can also be seen that the results of data processing in the 10 cohort studies conducted did not show any publication bias where there were 5 plots on the right and 5 plots on the left. On the left graph, it can be seen that the standard error is between 0 and 1.5 while the right of the standard error line is between 0 and 1.5 .

\section{DISCUSSION}

The results of data processing in a cohort observational design study using a metaanalysis showed that the use of antiplatelet drugs effectively reduced mortality in COVID19 patients. Similar results were found in a study conducted in England by Abu-Jamous et al. (2020) and Benson et al. (2021); Israel by Merzon et al. (2021); Poland by Terlecki et al. (2021); China by Yuan et al. (2020); America by Osborne et al. (2021) and Sahai et al. (2021).

Different research results were found in the study conducted in Spain by Corrochano et al. (2021); Germany by Fröhlich et al. (2021); America by Tremblay et al. (2020). From these three studies, the results showed that COVID-19 patients who received antiplatelet drugs had a higher risk of dying than those without antiplatelet drugs. The three research teams propose that further studies, particularly prospective controlled trials, be undertaken to validate these findings and identify appropriate patients for whom antiplatelet therapy may be beneficial.

A meta-analysis of 10 cohort studies from the UK, Spain, Germany, Poland, America, Israel and China that were processed using this meta-analysis showed that COVID19 patients receiving antiplatelet drugs had a 0.70 times risk of death compared to COVID19 patients who did not use/receive antiplatelet drug therapy $(\mathrm{aOR}=0.70 ; 95 \% \mathrm{CI}=$ 0.46 to 1.07; $p=0.100$ ). From these results, it can be concluded that antiplatelet drugs have been shown to have effectiveness in reducing mortality in COVID-19 patients, but the effect is less strong.

The results of this study support the theory that the use of antiplatelet drugs is effective in reducing mortality in COVID-19 patients. This meta-analysis study can also be used as an information and reference material for further meta-analytical research. In addition, it can be a reference for conducting research related to the effectiveness and effect of using antiplatelet drugs in reducing the mortality rate of COVID-19 patients.

The practical implication is that health or clinical personnel, especially policymakers/health service managers and health stakeholders, can prevent and reduce the mortality/mortality of patients with cardiovascular system disorders in the disorders platelet aggrega-tion due to COVID-19.

Researchers recommend that further study can be conducted regarding the effectiveness of using antiplatelet drugs in reducing mortality in COVID-19 patients with a larger number of study subjects. In addition, the country being analyzed can be more broadly and use other influencing factors, such as a history of disease and other drugs used concurrently.

This study cannot be used as a recommendation for clinical practitioners or related health workers to use the results of this study (antiplatelet drugs) as an effort to reduce mortality in COVID-19 patients. Health policyholders are expected to be able to contribute to disseminating the results of this study so that unexpected things do not happen.

\section{AUTHOR CONTRIBUTION}

Happy Nurhayati is the main researcher who chose the theme, searched for, and collected the data. Eti Poncorini Pamungkasari and Bhisma Murti analyzed the data and reviewed study documents. 
Nurhayati et al./ Antiplatelet Drugs Uptake in Decreasing Mortality in COVID-19 Patients

CONFLICT OF INTEREST

There was no conflict of interest in this study.

FUNDING AND SPONSORSHIP

Any party did not fund this study.

\section{ACKNOWLEDGEMENT}

We are very grateful to the database providers which are PubMed, Science Direct, Scopus, and Google Scholar.

\section{REFERENCES}

Aaronson PI, Ward JP, Connolly MJ (2013). The Cardiovascular System: At a Glance. 4th edn. New Jersey: Wiley Blackwell.

Abu-Jamous B, Anisimovich A, Baxter J, Mackillop L, Vizcaychipi VP, McCarthy A, Khan RT (2020). Associations of comorbidities and medications with COVID-19 outcome: A retrospective analysis of realworld evidence data. medRxiv. pp: 1-18.

Aghajani MH, Moradi O, Amini H, Tehrani HA, Pourheidar E, Rabiei MM, Sistanizad M (2021). Decreased in-hospital mortality associated with aspirin administration in hospitalized patients due to severe COVID-19. J. Med. Virol. 93(9): 53905395. doi: 10.1002/jmv.27053.

Benson RA, Nandhra S (2021). Outcomes of vascular and endovascular inter-ventions performed during the coronavirus disease 2019 (covid-19) pandemic the vascular and endovascular research network (vern) covid-19 vascular service (cover) tier 2 study. Ann. Surg. 273(4): 630-635. doi: 10.1097/SLA.0000000000004722.

CEBMa (2014). Critical Appraisal for crosssectional study. Amsterdam.

Chow JH, Khanna AK, Kethireddy S, Yamane D, Levine A, Jackson AM, McCurdy MT, et al. (2021). Aspirin Use Is Associated with Decreased Mechanical Ventilation, Intensive Care Unit Admission, and InHospital Mortality in Hospitalized Patients with Coronavirus Disease 2019.
Anesth. Analg. 132(4). 930-941. doi: 10.1213/ANE.0000000000005292.

Corrochano M, Acosta-Isaac R, Mojal S, Miqueleiz S, Rodriguez D, Quijada-Manuitt MA, Fraga E, et al. (2021). Impact of preadmission antithrombotic therapy on disease se-verity and mortality in patients hospitalized for COVID-19. Journal of Thrombosis and Thrombolysis. Springer. 2019(0123456789). doi: 10.1007/s11239021-02507-2.

Diaz T, Trachtenberg BH, Abraham SJK, Sharaf RK, Durant-Archibold AA(2020). Aspirin Bioactivity for Prevention of Cardiovascular Injury in COVID-19. Front. Cardiovasc. med. 19-22. doi: 10.3389/fcrm.2020.562708.

Fröhlich GM, Jeschke E, Eichler U, Thiele H, Alhariri L, Reinthaler M, Kastrati A, et al. (2021). Impact of oral anticoagulation on clinical outcomes of COVID-19: a nationwide cohort study of hospitalized patients in Germany. Clin Res Cardiol. Springer Berlin Heidelberg: 110(7): 1041-1050. doi: 10.1007/s00392-020-01783-x.

Harthi AA, Sulaiman KA, Aljuhani O, Korayem GB, Altebainawi AF, Alenezi, RS, Harbi SA, et al. (2020). Evaluation of low-dose aspirin use among COVID-19 critically ill patients : A Multicenter Propensity Score Matched Study. Clin Res Cardiol. 1-17.

Karruli A, Booccia F, Gagliardi M, Patauner F, Ursi MP, Sommese P, Rosa RD, et al. (2021). Multidrug-Resistant Infections and Outcome of Critically Ill Patients with Coronavirus Disease 2019: A Single Center Experience. Microb. Drug Resist. doi: 10.1089/mdr.2020.0489.

Levani, Prastya and Mawaddatunnadila (2021). Coronavirus Disease 2019 (COVID-19): patogenesis, manifestasi klinis dan pilihan terapi' ('coronavirus disease 2019 (COVID-19): pathogenesis, clinical manifestations and treatment options). Jurnal Kedokteran dan Kesehatan. 17(1): 44-57. 
Nurhayati et al./ Antiplatelet Drugs Uptake in Decreasing Mortality in COVID-19 Patients

Received from https://jurnal.umj.ac.id/index.php/JKK/article/view/6340.

Liu Q, Huang N, Li A, Zhou Y, Liang L, Song Q, Yang Z, et al. (2021). Effect of low-dose aspirin on mortality and viral duration of the hospitalized adults with COVID-19. Medicine: 100(6).e24544. doi: 10.1097/MD.00000000000-24544.

Meizlish ML, Goshua G, Liu Y, Fine R, Amin K, Chang E, DeFilippo N, et al. (2021). Intermediate-dose anticoagulation, aspirin, and in-hospital mortality in COVID-19: A propensity score-matched analysis. Am. J. He-matol. 96(4): 471-479. doi: 10.1002/ajh.-26102.

Merzon E, Green I, Vinker S, Golan-Cohen A, Gorohovski A, Avramovich E, FrenkelMorgenstern M, et al. (2021). The use of aspirin for primary prevention of cardiovascular disease is associated with a lower likelihood of COVID-19 infection. FEBS Journal. 1-11. doi: 10.1111/febs.15784.

Mura C, Preissner S, Nahles S, Heiland M, Bourne PE, Preissner R. (2021). Realworld evidence for improved outcomes with histamine antagonists and aspirin in 22,560 COVID-19 patients. Signal Transduct Target Ther. 6(1). doi: 10.1038/s41392-021-00689-y.

Murti B (2018). Prinsip dan Metode Riset Epidemiologi (Epidemiological Research Principles and Methods). V. Surakarta: Program Studi Ilmu Kesehatan Masyarakat.

Neal MJ (2015) Medical Pharmacology at a Glance. Eighth. New Jersey: Wiley Blackwell.

Osborne TF, Veigulis ZP, Arreola DM, Mahajam SM, Roosli E, Curtin CM (2021). Association of mortality and aspirin prescription for COVID-19 patients at the Veterans Health Administration. PLoS ONE: 16(02): 5-14. doi: 10.1371/journal.pone.0246825.

Rakhmawati N, Paryono, Setyaningsih I (2019).
Resistensi antiplatelet pada stroke iskemik. Berkala Neurosains. 18(1): 1-7.

Retnawati H, Apino E, Kartianom, Djidu H, Anazifa RD (2018). Pengantar Analisis Meta Yogyakarta: Parama Publishing.

Sahai A, Bhandari R, Godwin M, McIntyre T, Chung MK, Jean-Pierre I, Kamran H, et al. (2021). Effect of aspirin on short-term outcomes in hospitalized patients with COVID-19. Vascular Medicine (United Kingdom). doi: 10.1177/1358863X211012754.

Siddaway AP, Wood AM, Hedges LV (2019). How to do a systematic review: A best practice guide for conducting and reporting narrative reviews, meta-analyses, and meta-syntheses. Annu. Rev. Psychol. 70: 747-770. doi: https://doi.org/10.1146/annurev-psych-010418-102803.

Son M, Noh M, Lee JH, Seo J, Park H, Yang S (2021). Effect of aspirin on coronavirus disease 2019. Medicine: 100(30): e26670. doi: 10.1097/md.0000000000026670.

Susilo A, Rumende CM, Pitoyo CW, Santoso WD, Yulianti M, Herikurniawan, Sinto $\mathrm{R}$, et al. (2020). Coronavirus Disease 2019: Tinjauan literatur terkini. Jurnal penyakit dalam indonesia (Recent Literature Review). Acta Med Indones. 7(1): 45. doi: 10.7454/jpdi.v7i1.415.

Terlecki M, Wojciechowska W, Klocek M, Olszanecka A, Stolarz-Skrzypek K, Grodzicki T, Małecki M, et al. (2021). Association between cardiovascular disease, cardiovas-cular drug therapy, and inhospital outcomes in patients with COVID-19: Data from a large singlecenter registry in Poland. Kardiologia Polska: 79(8): 773-780. doi: 10.33963/KP.15990.

Tremblay D, Gerwen MV, Alsen M, Thibaud S, Kessler A, Venugopal S, Makki I, et al. (2020). Impact of anticoagulation prior to COVID-19 infection: A propensity scorematched cohort study. Blood: 136(1): 144- 
Nurhayati et al./ Antiplatelet Drugs Uptake in Decreasing Mortality in COVID-19 Patients

147. doi: 10.1182/BLOOD.2020006941.

Yuan $\mathrm{SH}$, Chen P, Li H, Chen $\mathrm{CH}$, Wang F, Wang DW et al. (2021). Mortality and prehospitalization use of low-dose aspirin in
COVID-19 patients with coronary artery disease. J Cell Mol Med. 25(2): 1263-1273. doi: $10.1111 /$ jcmm.16198 